\title{
Trust as Glue in Nanotechnology Governance Networks
}

\author{
Heidrun Åm
}

Received: 17 December 2010 / Accepted: 7 March 2011 / Published online: 6 April 2011

(C) The Author(s) 2011. This article is published with open access at Springerlink.com

\begin{abstract}
This paper reflects on the change of relations among participants in nanotechnology governance through their participation in governance processes such as stakeholder dialogues. I show that policymaking in practice - that is, the practice of coming and working together in such stakeholder dialogues - has the potential for two-fold performative effects: it can contribute to the development of trust and mutual responsibility on the part of the involved actors, and it may bring about effects on the formation of boundaries of what is sayable and thinkable in nanotechnology governance. Three vignettes about the work of the German NanoKommission indicate the development of new relations of trust, recognition and mutual responsibility among actors. It is concluded that governance in practice can assemble new collectives in which relations of trust are the glue holding the complex structure together. While such a consensus-based progress may be favourable for smooth technology development, it can be considered problematic if evaluated against the ideals of deliberative democracy, which often form the premises on which public engagement is based. Stakeholder forums were set in place with the intention of including various actors, but this is Janus-faced: if a dialogue becomes
\end{abstract}

H. Åm $(\bowtie)$

Vienna School of Governance, Department of Political

Sciences, University of Vienna,

Universitätsstrasse 7/2. Stock,

1010 Vienna, Austria

e-mail: heidrun.am@univie.ac.at encapsulated in new governance networks, new exclusions can arise. For example, a policing of which information is released to a wider audience can occur.

Keywords Nanotechnology governance - German nanotechnology politics - Governance networks . Deliberative democracy $\cdot$ Performative trust $\cdot$ Public dialogue $\cdot$ Public engagement

\section{Introduction}

On a November morning in 2009, I conducted my last interview in a week of meeting people involved in nanotechnology governance in Germany. In these interviews, a narrative approach was pursued that aims to elicit detailed descriptions of a situation and how it was endowed with meaning [36, 37]. Hence, questions would be asked such as 'What was the first time there was any kind of consciousness in your agency that nanotechnologies might be worth a second thought?' and 'Could you give me a concrete instance of when that actually happened, using as much detail as you can?' Thus, that was what I did or tried to do on this particular November morning, as well. Except that this time it did not work. I was able to elicit only very general accounts of what had happened in the stakeholder meetings or public dialogues in which the interviewee had been participating. For example, the interview showed the following pattern of question and response: 
Interviewer: 'You mentioned that it took much time to agree on a definition of nanotechnology within the varied group of stakeholders. The final position paper presents one definition. Could you walk me through the process of reaching this agreement?'

Respondent: 'Well ... we started with defining nanotechnology within the range of $1 \mathrm{~nm}$ and $100 \mathrm{~nm}$, but some environmental organisations had objections to drawing the line at $100 \mathrm{~nm}$ because there could be risks above this range. So, we discussed it further in a long process and finally we reached an agreement.'

Rephrasing the question several times did not help, and the answers to other questions were similarly vague and undetailed. I introduce this interview quote here not for its content but to show that the elicited material was definitely far from being a rich narrative account of the practices of nanotechnology governance. In the course of the interview, as I wondered why things were now going wrong, I considered that there could be several reasons why the interview was unproductive. Did the interviewee just not understand what I meant when I described my interview style in the beginning, or was the respondent simply not talkative? Nevertheless, the consistency with which tricky topics were circumvented throughout the interview gave me the impression that the respondent did not want to tell me what I needed to know. Frustrated about the interview going badly and feeling that it was a waste of our time, I began to conclude the interview after only about 40 minutes. I did not mention anything about my evaluation of this interview to my respondent. But — as Paul Watzlawick put it in his meta-communicative axiom of his communication theory: you cannot not communicate. Indeed, I must have expressed my disappointment about the interview nonverbally.

And at that point the interviewee suddenly started to talk. What followed was a rich description of how these dialogue processes had developed in the last four years, how people got to know each other, how civil society organisations became increasingly knowledgeable about the topic, and how they were able to lead more sophisticated discussions now than in the beginning. The respondent's concluding statement was

Respondent: 'Thereby, we [the stakeholders] are taken more seriously, as partners on an equal footing. That was not like this from the beginning. By knowing each other better, one trusts the other and [then] talks about things that must not be made public, but this is very important background information. ... Yes, I think, it is important in such matters to trust each other and to be able to ask the questions one could not ask if the discussions were public.'

I nodded and accepted the apology, as it were. Only months later, when I had the opportunity to participate in a workshop on nanotechnology and trust, did I recall the anecdote, which made me think further: Which consequences for democratic governance do the relations have that are built among stakeholders when they gather on a regular basis to talk about nanotechnologies? I argue that members of stakeholder forums are temporally united by relating different interests to the common project of 'the responsible development of nanotechnology.' A 'we' in governing can arise among previously disparate subject positions which are transformed by new relations of trust und mutual responsibilities.

\section{Context: Public Engagement in Nanotechnology}

Developments in nanotechnology politics must be seen in the broad context of changes in policy-making away from government towards governance, 'governance' being a term introduced to capture a variety of actors, institutions and sites involved in doing politics, in formulating policy problems and in finding solutions to key problems. Between state institutions and social organisations, among state institutions, and in subpolitical movements and citizen groups, a range of new political practices has developed that develops political agendas apart from the institutions of the classical modernist states ([13]:i). Such new political practices can take the form of citizen juries, citizen movements, collaborative dialogues, stakeholder forums, informal policy networks, officially assembled governance networks, etc. New in these practices are not only the way of conducting policy (new sites, new actors), but also the themes (ibid., p. ii).

At the same time, a new ethos is guiding these efforts, an ideal of participation, inclusion and deliberation. There are considerable differences in the conception, aims and means of deliberative democracy that are 
beyond the scope of this article. But a common denominator of deliberative ideals is that, in a democratic polity, political decisions shall be taken by free and equal citizens [24]. Deliberative democracy implies that collective decisions shall be taken by all those affected by the decisions; and decision-making itself shall be characterized by a reasoned exchange of arguments among the participants ([6]: 8). In short, deliberative or participatory governance settings shall be more inclusive, less hierarchical and consensus based.

In particular the field of emerging technology, which was classically dominated by expert knowledge and technocratic decision-making in closed bodies, was a site where settings of participatory governance developed after food scandals such as bovine spongiform encephalopathy (BSE), after social movements arising around a rejection of genetic modification, and in the light of increasing uncertainty of the application of new scientific knowledge and the consequent dislocations of conventional ways of regulation. Both motivations (an inclusion of a wider public to preclude a contestation, as well as uncertainty about how to deal with this new thing) rank high in nanotechnology governance and have entailed a demand for public engagement in the governance of nanotechnology. These increased efforts in public engagement in nanotechnology governance are intertwined with a perceived deficit of trust in technologies and the attempt to create good relations between technology and society ([3]: 203). From the beginning, a demand for engaging the public was articulated with nanotechnology - a demand for inviting voices, for understanding public understandings, for learning the lessons and for doing the right thing the first time [2, 7, 17, 21, 22, 28]. Consequently, many and various efforts of public engagement in nanotechnology were initiated.

While there was an embracing of public engagement from the beginning, the ethical, legal, and social issues (ELSI) literature also conveyed a certain suspicion that such engagement might primarily serve to convince publics ([3]: 206, [5]: 14) about the benefits of nanotechnology rather than offer them real choice and decision-making power. Such an instrumental use of participatory governance runs counter to ideals of transparency and inclusion. Increasingly, demands arise in the science and technology studies (STS) community for a critical engagement about the challenges and pitfalls of public participant and public engagement [5]. This paper contributes to that discussion by drawing attention to the performative side effects of bringing people together that are commonly not taken into consideration. What does it mean - set against the background of deliberative ideals - that the interviewee defined the stakeholder forums as closed circles in which discussions could be led distanced from the public?

I argue that stakeholder forums like the German NanoKommission can contribute to the forming of new identities and the creation of a new style of governance that is marked by new relations of trust among actors who might have previously entered into controversies about an emerging technology. The aim of the article is not to diminish the considerable efforts and outputs of stakeholder dialogues but to trigger reflections on the effects of such participatory governance, which might not be immediately obvious. I show that policymaking in practice - that is, the practice of coming and working together in such stakeholder dialogues - has the potential for two-fold performative effects: it can contribute to the development of trust and mutual responsibility of the involved actors, and it may bring about effects on the formation of boundaries of what is sayable and thinkable in nanotechnology governance. I assume that the danger of this is that the discussions become encapsulated and dislocated from a wider audience - thus, I point to the danger that the practice of participation can turn its premises of inclusion and transparency into its opposite.

\section{Performative Dimension of Trust and Policy as Practice}

The composition of nanotechnology stakeholder forums often starts from the assumption that a balance of interests should be represented in the forum. For example, when the UK Department of Environment, Food and Rural Affairs (Defra) set up its nanotechnology stakeholder forum, it aimed to bring different interests to the table. The stakeholder forum participation was based on invitation. The organisers tried to arrange a balance of interests by bringing together green NGOs, consumer groups, academics and industry stakeholders so they would challenge one another within the given setting of a stakeholder forum. The literature indicates that such forums seem to demonstrate that incorporation into political rule is ideally taking place across public and 
private, leaders and led, expert and layperson. The aim is to overcome incommensurable interests by constructing a shared information basis and mutual understandings ([8]: 545).

The theoretical perspective of this paper rejects simplified premises onto which stakeholder dialogues are formed and invites for considering them as more complex and fluid arrangements. Even before the stakeholder dialogues start, dichotomies (lay-expert, public-private, NGO-industry) and respective interests might not be as stable and predetermined as is often perceived but they are in fact dependent on context and on discursive constructions of who counts as an actor and who does not; and on how, through practices of articulation and inscription, policy problems rise and actors position themselves around them [11]. In addition, the clarity of political cleavages or the continuity of what political actors stand for might be more vague and elusive in an age in which politics goes beyond classical institutions of the state, where new media have created new political stages, and where the publics become highly fragmented and individualised [14]. Apart from that, I argue that the participation of stakeholders in these forums and series of meetings mobilizes their understanding of the policy problem and changes the role they take in the policy field. Thus, I open the way for a reflection of the concept of stakeholder forum as more fluid complexes in a two-fold way: the premises on which they are built are not as clear-cut as often perceived, and their enactment leads to transformation so that the composition of the forum may end up as something quite different from its initial concept.

By the term 'enactment', I use Hajer's definition: 'when people act, they bring events and structures into existence and set them in motion, producing constraints and opportunities that were not there before they took action' ([14]: 7). Thus, acting in governance networks, for example in meetings, by correspondence or when composing drafts, creates new perspectives - not only on the issue at hand, that is, nanotechnology, but also - and this is my focuson relations among the actors. That identity building is taking place in deliberative policy making has already been pointed out in the literature on deliberative policymaking and in 'policy as practice' approaches. As Wagenaar and Cook write in a chapter of Maarten Hajer and Henk Wagenaar's well-known book on deliberative policy analysis [35]:
'Problem solving in the practice paradigm is [...] more the discovery of preferences, positions and identity; it is finding out where one stands in relation to the problem at hand, what we value in this particular situation, who we are in relation to the others who are involved in the issue. Success is not measured in terms of the one best solution, [...] but rather, as Taylor observed, in terms of transitions.'

([35]: 168)

Meetings in nanotechnology stakeholder forums or commissions thus involve, first, members scanning the other people, and then, reflecting and positioning themselves and the institution they represent toward what they consider to be the relevant issue in nanotechnology. This is a dynamic process, and transformations are triggered by the participation in the events. Innes \& Booher make a similar observation:

'In collaborative policymaking, agreements are only a small part of the purpose and the consequences. The real changes are more fundamental and typically longer lasting and more pervasive than agreements.'

([15]: 55)

Innes and Booher talk about changes that are achieved through collaborative policymaking such as shared meaning, networks or new ways of understanding. To that list I would add trust relations and mutual responsibility. Even if the generation of trust is mentioned in the deliberative policy making literature, it is not considered from a performative perspective. I suggest that we can beneficially think further about 'what collaborative policymaking does in practice' by introducing Bron Szerszynski's considerations on the performative dimension of trust. My aim is to complement Innes \& Booher's and Wagenaar \& Cook's arguments that identities change, by an explanation of what this transformation of identities triggers. For this purpose, I draw on a paper by Bron Szerszynski [31] that suggests that performing trust transforms social identities and relationships.

Searching social sciences' databases for work on trust generates abundant relevant hits. These studies on trust cover, however, diverse parts of our social reality. Some research finds that trust works as a regulatory mechanism in society that can, for 
example, explain cooperation among social actors; other studies see it as a public good [23] that, for example, plays a role in the acceptance and perception of risk ([27]: 961). Depending on its application, the definition of the concept varies and yet often remains vague. Luhmann even starts his book on trust by reflecting on whether it is prudent to consider moral words of everyday usage for sociological theories ([20] preface). He famously argues that the main function of trust is to reduce the complexity of reality and that trust always refers to expectations about actions in the future.

Regarding trust relations, an important aspect of stakeholder forums is that people meet in person. In his essay on living in a post-traditional society, Giddens [9] points out how trust necessarily often has to be vested in a multiplicity of abstract systems in contrast to traditional systems of trust, which develop based on face-to-face meetings. He says:

'The disembedded characteristics of abstract systems mean constant interaction with "absent others"- people one never sees or meets but whose actions directly affect features of one's own life.'

([9]: 89)

Although Giddens thus stresses the importance of the shift of locations of trust, he does not abandon traditional forms of trust. On the contrary, he suggests that personalized trust, based on deliberately cultivated, face-to-face relationships, might be increasingly important in a period of high modernity (Misztal 1998: 90). This might be true for nanotechnology stakeholder forums: The person who represents industry associations or NGOs in these meetings becomes the 'face' of the stakeholder organization he or she represents, and the regular gatherings allow for developing interpersonal relations among these 'faces'. If we apply what Luhmann [20] says about other human beings bringing complexity into the world due to the unpredictability of their actions, then trust is first and foremost vested in other people by recognising them as the ordering centre of the systems of actions. Trust is in this respect a generalised expectation that a person will deal with a situation according to his or her personality. 'Trustworthy' applies to the person who stays consistent with what he or she consciously or not has told about himself or herself ([20]: 48).
Giddens' focus is on deliberately cultivated, faceto-face relationships. He and Ulrich Beck emphasise in their work on reflexive modernity and the posttraditional society that mechanisms of trust shift from being taken as granted towards an active trust 'that has to be energetically treated and sustained' ([10]: 186). Bron Szerszynski [31] embraces the notion of 'active trust,' but he suggests that trust is active in a stronger sense. Instead of considering trust as a cognitive judgement, Szerszynski proposes to see trust as 'an attempt to bind the 'trusted' into a relationship and attitude of responsibility - and thus perhaps to alter their behaviour-through the taking up of a position in a social ritual' ([31]: 239, emphasis added). He joined performative theory on language and speech acts with the trust concept. According to the performative theory on language set out by Austin, speech and gestures are performing acts that can change a definition of a situation or its constituent social relations (Austin 1975 cited by [31]). Austin's classical examples were that when I say 'I baptize you' or 'I bet', I am not describing a situation but rather I am doing things with words; these are examples of performative sentences ([1]: 6). Austin differentiated between 'illocutionary' acts (to inform, to warn, to order) and 'perlocutionary' acts (the achievement by saying something, e.g., a person is alarmed or astonished) (ibid: 108, 120). Accordingly, the expression of trust can be interpreted as a perlocutionary act that may aim at bringing about effects, such as being persuaded or being alarmed, in the addressed party (Austin 1975 cited by [31]: 246). Thus the language of trust or distrust might not be so much about representing the world, but it is in a way selffulfilling: if everybody behaves as if everybody is trustworthy, then they will be so ([31]: 246).

'From this perspective, trust is less a matter of individual discernment and cognition and more like a kind of social glue that binds people into generalised relations of mutuality.'

([31]: 247)

That is to say that Szerszynski introduces an interpretation of expressions of trust as an attempt to make the entrusted fulfil obligations, to make somebody do what he or she does normally not do. He gives the example of a resident approaching the operator of a local chemical plant to elicit safety information. This act could be interpreted as an 
assertive ('you are trustworthy'), as an expressive ('I feel I trust you') or as declarative ('I declare my dependency on you') ([31]: 248). The latter is what Szerszynski focuses on: directive declarations that seek to bring about perlocutionary effects on the addressee, for example, that the company shall live up to its safety responsibilities (248).

Thus, if an exchange of information, ideas and positions is taking place in these stakeholder forumslike the respondent in my interview said: 'By knowing each other better, one trusts the other and [then] talks about things that must not be made public'-the participants are 'performing illocutionary acts of 'entrusting' on others' ([31]: 247), which bind the members of the forum or commission into a relationship of responsibility. In the following, I draw on examples of nanotechnology politics to illustrate further how performative trust in new governance relations can cause identity changes.

\section{Performing Borders: What is Sayable in Nanotechnology, and Where?}

Vignette 1-From an Outsider to a Trustworthy Partner

Let's review the full quote problematised in the introduction of this paper:

Respondent: 'Thereby, we [the stakeholders] are taken more seriously, as partners on an equal footing. That was not like this from the beginning. By knowing each other better, one trusts the other and [then] talks about things that must not be made public, but this is very important background information. ... Yes, I think, it is important in such matters to trust each other and to be able to ask the questions one could not ask if the discussions were public.'

Approached from the perspectives of the introduced theoretical frame, it can be seen how the respondent stressed a temporal dimension in which a transformation of relations among the stakeholders involved in the forum took place. The interviewee mentioned first how civil society organisations would become more knowledgeable about the subject and then concluded that this transformed their role in the stakeholder forum from that of outsider to that of being one of the inner circle. At the same time, the people who participated in the forums as representatives of their organisations, companies, unions or political institutions learned more about each other and became acquainted with each other. Thus, through the members enacting deliberations on nanotechnology, the way of relating to each other changed to become relations between trustworthy partners. By exchanging information with each other that previously would have been disclosed only to certain members of the forum, it was not only acted upon the relation of trust, but the relation was at the same time extended to a relation of mutual responsibility. Individuals became bound within each other so that to pass on secretly told information would result in a serious disruption of any carefully accrued relation-this disruption would occur not only with the actor whose secrets one had been revealed, but might result in one being discredited beyond the group and indeed their organisation losing credibility as a partner in nanotechnology governance.

The respondent took part in several stakeholder dialogues in Germany, particularly in the German NanoKommission, which was created after two big NanoDialogue events organised by the Federal Environment Ministry in 2005 and 2006. As the central national dialogue committee, the NanoKommission took over the task of evaluating risks and benefits of an emerging technology about which there was still insufficient knowledge. It began its work in late 2006 and established a regular stakeholder dialogue. Participants were representatives of government (ministries and agencies, federal and states), industry, science, trade unions and civil society organisations. The three NGOs present were the BUND (Friends of the Earth Germany), the Federal Consumer Protection Agency (Verbraucherzentrale) and a citizen initiative on environmental protection (Bundesverband Bürgerinitiativen Umweltschutz). Industry-represented by industry associations, for example, the Association of Chemical Engineers (VCI), and by major companies such as chemical companies BASF, Merck or Evonik, and smaller nanotechnology-basedcompanies such as LtN Nanovation AG-outnumbered in the commission itself as well as in two of the commission's three working groups. Three working parties, 'Chances for Environment and Health', 'Risk 
and Security Research' and 'Guideline for a Responsible Development of Nanotechnologies,' tackled those specific areas. The titles of the working parties reveal the work programmes the NanoKommission considered important: name the chances, gather information on risk, and reflect on whether and how we can govern despite uncertainty (which measure could be taken when lacking evidence). The chair of the NanoKommission was Wolf-Michael Catenhusen, a former state secretary, former employee of the Federal Ministry for Research and Education, and a member of the German Social Democratic Party. He was already an important figure in biotechnology debates in the 1990s and, apart from the NanoKommission, he also sat on ethics committees in 2009.

The efforts of building a NanoKommission must be seen against the background of the German regulatory discourse on nanotechnologies in which an open, flexible regulation was demanded that would enable innovation. These conceptions were well outlined in a text by a former departmental leader of the German Environment Ministry, Uwe Lahl. He suggested [19] that codes of conduct could replace statecontrolled, legal regulation in nanotechnology governance. Instead of regulation by law, regulation shall be developed that is decentralised in a modus where industry could come to an arrangement on obligatory self-regulation with consumer organisations and environmental organisations. Thus, industry would benefit from this cooperation by being made alert of potential risk areas by the civil society organisation, and NGOs in turn would receive information on new manufacturing processes and products and also have the opportunity to ask questions ([19]: 52). With the following vignette, I explore how the role of the NGO BUND in the political process was challenged by its inclusion in the NanoKommission.

Vignette 2-BUND (Friends of the Earth Germany) in the Nanokommission

While the NanoKommission was at work building stable conditions for a trustworthy dialogue among participants, the NGO BUND published a German version of a critical position paper, which was composed in a cooperation of 70 NGOs worldwide, in which they positioned themselves as an NGO acting on nanotechnology issues. While they were sitting on the NanoKommission, the most important
German discussion circle, the BUND's position paper was published in August 2008, making it clear that Friends of the Earth Germany were about to challenge the hegemonic discourse of nanotechnology, in which nanotechnology leads to a promising future. The position paper was already preceded by the publication of a critical study of the BUND published in March 2008. Both documents addressed the Achilles' heel of nanotechnology governance: with an attempt to interrupt these articulations of nanotechnologies that were linking the field with economic growth and future well-being. In contrast to the fancy promises of nanotechnology, it drew a picture of mundane, small nanotechnology applications sweeping the market, and warned that these applications might bear risks for human beings and the environment but might slip through risk assessment in the mad rush to implement them. It read:

'Nanotechnology is praised as a key technology of the 21 st century. Climate change, world hunger and diseases shall be combated by means of nanotechnologies. Having a close look at nanoproducts available on the market is, however, disenchanting: an increasing and vast number of daily products with questionable benefits are urged onto the market, while we still have to wait for breakthroughs in environment technologies that the industry had conjured. Instead, more and more frequently there are products on the shelves in the shops that contain nanomaterials like textiles, food, cosmetics, cleansing devices, sealing sprays, sports articles and toys.

At the same time, many open questions remain unsettled: How do nanomaterials behave if they are taken up by the body or if they get into the environment? Can nanomaterials that appear bound within matter be released through abrasion or disposal? Should not citizens participate in deciding the direction of technology development, or should this continue to be left to industry?

While the marketing of nanoproducts continues, there are no laws worldwide regulating the use of nanomaterials. [...]'

(BUND August 2008)

Thus, the position paper introduced nanotechnology as something ubiquitous, mundane, potentially harmful, 
and uncontrolled. The line of reasoning contested the picture of nanotechnology as a beneficial development. The paper outlined the requests of the environmental organisation: nanotechnology should be approached by means of the precautionary principle - this included a moratorium on products for which the safety could not be proven-because the first results of risk research on nanomaterials indicated toxicity of certain nanomaterials, according to BUND. Thus, an argument of quality on the interpretation of first-risk studies was made. As we see below, the toxicologist Harald Krug, professor for material biology interactions at the Swiss Federal Government Laboratories for Materials Science and Technology (EMPA), suggests a different interpretation of first-risk research results. The principal demand of BUND was nano-specific, obligatory risk-regulation. In contrast to other participants of the NanoKommission who were desiring voluntary codes, this NGO wanted binding rules on nanotechnology, and, specifically, compulsory regulations with monitoring and sanctions. Thus, while the work in the NanoKommission was going on, the NGO attacked voluntary agreements on nanomaterials from several angles. The NGO argued that, without sanctions, companies might skip longlasting and costly studies on long-term effects of the nanomaterials. Another shortcoming of voluntary codes from their perspective concerned the industry's black sheep: even if those manufacturers who were dedicated to the environment and to protecting human health would do a good job on a voluntary basis, exactly those who needed control most could cause harm ([4]: 5). In addition to their request for obligatory regulations, BUND was a proponent of a public register that, together with product labelling, should lead to transparency - a move that industry rejected due to the data protection needed in the fierce competition among companies.

How should the NanoKommission deal with this strong, public positioning of one of its members? According to a civil servant interviewed for this study, the dominant interpretation of this incidence by members of the NanoKommission was that the NGO BUND had abused the trust that had accrued during the work of the commission. The situation created by the 2008 position paper was said to be very difficult, and as a result of the breach of trust, this NGO almost left the dialogue process. Interestingly for this 'special issue on nanotechnology and trust' is that the incident was mainly formulated as an issue of trust.
Approached from the perspective of Luhmann's theory on trust, one could argue that the reactions unveiled contradictions in the generalised expectations that members of the commission had concerning the implicit rules of behaviour that participation in the commission entails. However, this does not adequately explain the harsh reaction of accusing the NGO of abusing trust. Approaching it from an performative perspective, that is, that sitting on the commission was meant as an attempt to make all members behave in a certain way, to perform trust that binds the members into a 'we' of governing nanotechnology together, more accurately describes the dislocatory potential of the situation. The inclusion into the commission was part of setting the boundaries of how and where to talk about nanotechnology. A similar pattern is shown in vignette 3, which was not explicitly problematised as a trust issue in my interviews.

Vignette 3-The Federal Environment Agency Press Release Incident and Response

On October 21, 2009, the German magazine Der Spiegel [30] published an article stating that the Federal Environment Agency (Umweltbundesamt-UbA) had issued a warning about nanotechnology. The article reported that nanoparticles in food, clothes and cosmetics could lead to health risks and that there were no regulations in place yet. The media was drawing on a repertoire of fearful resources by stressing the invisibility of nanoparticles, their minuteness because of which particles could enter human cells, where they could potentially damage the human genome, and by stressing the similarity of nanotubes to asbestos.

By coincidence, I conducted interviews in Germany shortly after publication of the Der Spiegel article and subsequent media reports in which the UbA report was discussed. All interviewees mentioned the incident without being prompted about it, and their reactions ranged from surprise to astonishment to indignation. In the world of nanotechnology policy making in Germany, the Environment Agency's venture faced criticism. The overall impression was that the Environment Agency might have deliberately issued 'the warning' in a time (October 2009) when the Environment Ministry had no formal leader because of the recent (September 2009) federal elections and 
subsequent ongoing coalition talks. For example, Harald Krug, from the EMPA, who a spokesperson of the large research project consortia NanoCare in Germany, sent via an email-list an open email, which was later also published on a website, to the Environment Agency. The open letter demands answers to seven questions. The first question asked why the Environment Agency had referred to knowledge gaps in its press release instead of referring to the work already done, such as the work of the NanoKommission, of which the Environment Agency itself was also a member. Questions 2, 3, 5 and 6 identify ongoing or completed risk research funding programmes and projects and take issue with the fact that the Environment Agency had not mentioned them in the press release. The email also lists study results stating that nanoparticles do not carry risks. The final question reads as follows:

'7. Why do you not speak with experts beforehand, and why do you not let the information be proofread before releasing it in order to avoid misunderstandings instead of imposing the task on us of having to correct the picture in the hindsight?'

[18]

This last question is nothing less than a request that information be approved by the governance network; it demands the installation of a gatekeeper before something is made public. The call for experts is bold, considering that the department of the UbA is staffed by doctors of biology.

Asked about the incidence in my interview, the representative of the Federal Environment Agency explained that they considered themselves badly misunderstood by the media. An interviewee of the UbA pointed out discrepancies between the media's focus on risks in relation to the presentation of the $\mathrm{UbA}$; in addition, neither the press release nor the background report articulates a warning about. The press release titled 'Nanotechnology for Humans and for the Environment-Support Chances, Diminish Risks' indeed begins with the consequences of nanotechnologies for the environment - but only from a positive angle. It suggests that nanotechnology would bring benefits to the society and the environment, for instance, because lighter materials allow for the construction of lighter cars and lighter air planes, thereby reducing their petrol demand; or because nanotechnology-optimized lamps use electricity more efficiently and thus nanotechnology helps save energy. Then of course, the press release also mentions that the increased use of synthetic nanomaterials in products entails an increased prevalence of these materials in the environment. The effects of these materials on the environment and on human health, it states, are insufficiently researched:

'Nanotechnology offers substantial potential for ecological product innovations, but as well risks for the environment and for human health. There are serious knowledge gaps. It follows from that an extensive need for research and regulation. [...] The UbA recommends: The use of products which contain and might release nanomaterials should be avoided-as long as their consequences for human beings and the environment are to a large extent unknown.'

[34]

Even if the Federal Environment Agency did not exactly warn about nanotechnology in this release, it suggested a kind of voluntary moratorium, not a moratorium decided by regulators but a consumer suspension of using these products. The press release was issued on the occasion of a 2009 update of a background paper on nanotechnology. That 22-page report has three main sections: potential relief of environmental problems through nanotechnologies (Umweltentlastungspotentiale), potential problems for the environment and for human health by nanotechnologies (Umweltbelastungspotentiale), and the activities of the Environment Agency in the field. Overall, the UbA report presents a review of ongoing research activities and formulates demands such as further risk research, further research into providing evidence for positive effects of nanomaterials, and a recommendation to treat nanomaterials products cautiously as long as we do not know more.

While the Environment Agency did already in the introduction of the report what Harald Krug had in hindsight demanded from the agency—refer to different risk research programmes that were funded by the government and the EU- the UbA and Krug showed different emphases in their interpretations of the results of such risk research programmes. Krug focused on studies that showed that nanoparticles in, for example, sun cream, were not taken up by the skin cells and provided better skin protection and less severe problems for 
environment than conventional chemicals used in sun cream. The Environment Agency's, however, drew attention to risk research on nanotechnology, finding that

'The present risk research project on nanomaterials $[\ldots]$ indicates potential toxic effects of nanomaterials and gives cause for further research: It is currently too early for a widereaching risk evaluation because toxicological long-term examinations are missing and often there are no data about eco-toxicological consequences available.'

[34]

Thus, while one person prioritized first results that indicate there were no risks deriving from nanotechnologies, the other group focused on negative results. What was not spelled out after the incident, or even masked over, was the conflict of contradictory interpretations of risk result- $\mathrm{a}$ theme also represented in the incident with the NGO BUND in vignette 2 above.

The extent and consequences of this UbA incident must not be misunderstood. To clarify: media reports did not cause an outcry in public, nor did the incidence bring to an end any co-operation with the Federal Environment Agency in nanotechnology policymaking. But the reason for presenting the case here is that it reveals something about nanotechnology politics in Germany. First, what does it mean that most interviewees suspect that the Environment Agency acts because it had no formal leadership at the time? Second, it shows how alert actors involved in nanotechnology governance were; how they sitting in waiting to immediately police any transgression of silently defined borders of what can be said about nanotechnology and what can not. What I observed from the interviews I conducted after the press release was that the beams of the carefully erected, interwoven scaffolding of German nanotechnology politics were creaking. A discussion was triggered about what to let out of this scaffolding towards the ears of the wider public. The previously unsaid agreement was voiced that worries about nanotechnologies should be discussed internally within predefined and designated settings, such as the NanoKommission or the NanoCare research project, instead of starting a discussion in an open arena constituted by the media, where the uptake of the message and responses to potential worries cannot be controlled.

\section{Discussion: Against Dismissing the Political}

We can apply the notion of a 'governance network' on stakeholder forums such as the NanoKommission. Governance networks can be defined as

'A relatively stable, horizontal articulation of interdependent, but operationally autonomous actors who interact through negotiations that take place within a relatively institutionalized community which is self-regulating within limits set by external agencies and contributes to the production of public purpose.'

([32]: 5)

The possible merits of governance networks are as manifold as their various appearances. Because of their flexible and complex structures, they are, for example, considered as suiting for solving wicked problems by integrating actors, who might not have had a voice in traditional policy making, thus providing for a better basis for the acceptance of the policy output and contributing with their special knowledge. As an advantage, the resources, capacities and energies of private actors, which have been wasted earlier, are used, and the intense dialogical character of network participation generates mutual trust and knowledge ([32]: 13). Nevertheless, the claim is not unchallenged that governance networks lead to a more effective and democratic governance. Evaluated against traditions of liberal democracy, governance networks contradict democratic standards such as representation, free and equal access, and transparency. ([29]:200) In short, opening up the governance process can have side effects, such as new channels of influence, illegitimacy of the actors involved and the weakening of the established democratic system. However, in this case, the NanoKommission cannot be reproached for involving illegitimate actors. The commission has to be seen in a long tradition of Konzertierung-concerted action among social partners - in Germany. Normal German politics takes place in the administrative realm in properly constituted expert committees that 'function as miniworlds of reason: they aim to encompass within them the capacity to articulate all relevant arguments and to produce a consensus that is binding on society because it is, in effect, the consensus that society would have reached if it had been able to deliberate in common' ([16]: 289). 
Neither could it be held against the NanoKommission that it was weakening the established democratic system, because its explicit aim was to establish a consensus among stakeholders before the topic became politicised.

Indeed, the peculiarity of the NanoKommission is that it was active before normal politics started to work: it was conceptualised as pre-political discourse process. 'Pre-political' has two different meanings in this respect. First, it refers to 'pre-politics', that is, the aim to locate the politics of defining the policy problem away from conventional politics, such as party politics. Representing a cornerstone of the 'responsible development of nanotechnologies' with genetic modification as the 'dismissed other', the NanoKommission was the counterpart to the Enquiry Commission on Biotechnology, which was founded in 1984. As with the NanoKommission, the aim of a commission enquiring into biotechnology was to examine 'the prospects and risks', and the commission was chaired by Wolf-Michael Catenhusen. There are, however, considerable differences between the two commissions. The biotechnology commission was established in a context of the rise of social movements in Germany, controversies on nuclear power and the Green Party being voted into parliament in 1983 ([16]: 59). Being an official advisory instrument of the parliament, the biotechnology commission was properly vested with staff and decision-making-power; participants were politicians (represented according to their representation in parliament) and experts; and the commission was institutionalised on demand of party fractions in the parliament (an alliance of the Green Party and the Social Democrats) (ibid.). Thus, the Enquiry Commission was part of the parliamentary chain of governance, whereas the NanoKommission worked on behalf of the Environment Ministry and had only loose, informal bonds to the parliament. In contrast to the Enquiry Commission, the NanoKommission aimed at discussions taking place in this newly established governance network dislocated from normal politics.

The second sense of 'pre-political' in the NanoKommission's 'pre-political discourse process" means to avoid contestation and polarisation. The institutionalisation of these new arrangements between industry and NGOs was not considered to run smoothly from the beginning. The chair of the
NanoKommission was implemented as a central point to prevent forces, which appeared to have the likelihood of pushing off of each other, of moving away from the centre. Since the overall policy narrative situated nanotechnology within the context of former technology debates, initiators of the commission imagined the two opposing ends of the magnet to be NGOs on the one hand and industry on the other. Asked for his interpretation of why he was asked to assume the chair of the NanoKommission, Wolf-Michael Catenhusen said:

'This is maybe connected to members of the ministry of environment knowing my efforts in other technology politics discourses in Germany. Maybe they trusted that I have good foundations of trust with many stakeholders.'

(Wolf-Michael Catenhusen, interview material)

We see how trust is a highly valuated quality in establishing nanotechnology governance in Germany with its general aim of reaching consensus. It is this aim of 'reaching consensus' I would like to problematise because we should not try to dream of a society without disagreements:

'In politics the public interest is always a matter of debate and a final agreement can never be reached; to imagine such a situation is to dream of a society without politics. One should not hope for the elimination of disagreement but for its containment within forms that respect the existence of liberal democratic institutions.'

([25]: 50)

In general, any assessment of the democratic quality depends on the democratic norms against which networks are evaluated. Proponents of traditional liberal theories of democracy argue that governance networks undermine traditional institutions of elected governments (e.g., decision makers are not voted into the network) ([33]: 126). In contrast, Sørensen and Torfing [29] posit that governance networks might as well stimulate the development of new forms of democracy. Torfing [32, 33]) suggests that governance networks can prove democratic quality if they fulfil democratic demands such as that actors can contribute critically to defining and solving policy problems, that participation is facilitated by ambiguous terms (e.g. responsible development), that alternative views and critique is reacted upon, and 
that freedom, equivalence and accountability are provided for (2007: 127). In the NanoKommission, opposing views were thoroughly discussed and the final report allows for ambiguity and conflicting views. For example, the report discusses how it was impossible to give a general answer on risk-questions concerning nanomaterials due to their diversity and various application contexts:

'Considered from a scientific angle, general statements on nanotechnology cannot yet be seriously taken. But such simple answers are looked for by the public debate. Maybe the challenge is to deal with the inevitable complexity, to communicate this complexity and to make these steps of evaluating chances and risks transparent.'

[26]

This vagueness of the report represents a positioning in a field of ambiguity, uncertainty and complexity that does not aim at overcoming these fallacies for regulation. Overall, the final report rather reads like a discussion paper rather than the closure of a debate. The section by working group 3 on the 'responsible development of nanomaterials' even included a paragraph with the subheading 'Aspects Where We Could Not Reach Consensus.' The open style of the document is part of its aim to avoid polarisation, and the allowance for opposing views can be traced to the social logics of writing the report. Thus, measured against the democratic demands introduced by Torfing, the NanoKommission did a good job.

Nevertheless, these 'miniworlds of reason' stage publics and bring relations among 'stakeholders' into being that did not exist before their cooperation. I suggest that these efforts to avoid polarisation are based on a simplified conception of 'the political' as politics of predefined interests that have to be overcome. It ignores that 'social relations take shape and are symbolically formed' ([25]: 11) at the political level. Thus, we have to draw attention to 'the identity of the 'we' that is going to be created through a specific form of collective action' (Pitkin after [25]: 50), such as a NanoKommission. By relating different interests to the common project of 'the responsible development of nanotechnology', a temporal unity among the members of the NanoKommission might be reached that also transforms subject positions because subjects are woven into new constellations of social relations that generate trust and mutual responsibilities. If due to the efforts in stakeholder forums such as the NanoKommission, adversary claims are no longer publicly articulated, the project was successful in preventing a public politisation. At the same time, this is a political outcome because the NanoKommission contributes to ordering social relations. Thus, the NanoKommission cannot claim to be a pre-political discourse process.

If we relate this back to the general context of public engagement in nanotechnology, my argument is that important political decisions are concealed by their displacement into supposedly pre-political settings - a concealment which conflicts with ideals of transparency in deliberative democracy. This paper problematised the articulation of new governance instruments into deliberative ideals. The political in the seemingly apolitical must be highlighted in order to identify potential democratic pitfalls of new governance instruments. In the three vignettes, I showed three performative effects of 'coming together in stakeholder forums', which are political: identity formation, policing information and-as I will discuss in the next paragraph — setting the borders of what is discussable.

The practices of coming together in stakeholder forums produce constraints and opportunities for the relation between nanotechnology and society. When the members of the commission try to make sense of this vague thing nanotechnology is, they enact the relationship between nanotechnology and society in a way which implies that certain issues are ruled off the agenda. As Finlayson put it, they contribute to setting the boundaries of the political argument:

'Arguments of place are attempts to set the boundaries of political argument and may be particularly important since to rule certain issues off the agenda is to win before argument has begun.'

([8]: 555)

All three vignettes point to a policing of what is to be said about nanotechnology and what is not to be said in German nanotechnology governance. The boundaries of transgression are enacted by participating in new governance arrangements. The bitter response of Harald Krug to the UbA press release and the strong reaction of members in the NanoKommission on the BUND's position paper hint at what was not sayable in nanotech- 
nology governance; it hints at the limits of the discourse. The UbA broke a taboo- a taboo that had not been spelled out before but which became obvious by the act of breaking it. When defining the policy problem of nanotechnology and developing recommendations like codes of conduct in governance networks, participants are not only exchanging arguments, 'but [this is] also a performative process in which the boundaries of argumentation are defined' ([12]: 245). The demand that certain information should not reach the public, which was expressed by Krug in his open email as well as by the interviewee in the first vignette, show that acting together in governance networks produces constraints.

I argue that in these new governance mechanisms that are applied in nanotechnology, new identities are developing. A 'we' in governing arises among previously disparate stakeholders. The output of these forums or interdisciplinary research projects might not so much be the recommendations such as the codes of conduct that are issued but the most important output could be new relations of trust among the political actors. Governance in practice assembles new collectives and relations of trust are the glue of these complex structures.

Acknowledgements This paper was written during a research stay at the Department for Interdisciplinary Studies of Culture, NTNU Trondheim and I would like to thank my hosts. My work has been funded by the Vienna School of Governance, University of Vienna.

Open Access This article is distributed under the terms of the Creative Commons Attribution Noncommercial License which permits any noncommercial use, distribution, and reproduction in any medium, provided the original author(s) and source are credited.

\section{References}

1. Austin JL (1962) How To Do Things With Words. Oxford University Press

2. Balbus J, Denison R, Florini K, Walsh S (2006) Getting Nanotechnology Right the First Time. In: Hunt G, Mehta M (eds) Nanotechnology: Risk. Ethics and Law. Earthscan, London/Sterling, pp 130-139

3. Barnett J, Carr A, Clift R (2006) Going Public: Risk, Trust and Public Understanding of Nanotechnologies. In: Hunt G, Mehta M (eds) Nanotechnology: Risk. Ethics and Law. Earthscan, London/Sterling, pp 196-212

4. BUND (Friends of the Earth) (August 2008) Kriterien zur Kontrolle von Nanotechnologien und Nanomaterialien. Retrieved from http:/www.bund.net/fileadmin/ bundnet/publikationen/nanotechnologie/20080220_nanotech nologie_kontrolle_kriterien.pdf Last accessed Dec 9, 2010
5. Delgado A, Kjølberg K, Wickson F (2010) Public engagement coming of age: From theory to practice in sts encounters with nanotechnology. Public Understanding of Science. Published online 11 May 2010. doi:10.1177/0963662510353054

6. Elster J (1998) Deliberative Democracy. Cambridge University Press

7. Einsiedel E, Goldenberg L (2006) Dwarfing the Social? Nanotechnology Lessons from the Biotechnology Front. In: Hunt G, Mehta M (eds) Nanotechnology: Risk. Ethics and Law. Earthscan, London/Sterling, pp 213-221

8. Finlayson A (2007) From Beliefs to Arguments: Interpretive Methodology and Rhetorical Political Analysis. Br J Polit Int Relat 9(4):545-563

9. Giddens A (1994a) Living in a Post-Traditional Society. In Beck U, Giddens A, Lash S (Eds.) Reflexive Modernization. Politics, Tradition and Aesthetics in the Modern Social Order. Stanford University Press, pp. 56-109

10. Giddens A (1994b) Risk, trust, reflexivity. In: Beck U, Giddens A, Lash S (Eds.) Reflexive Modernization. Politics, Tradition and Aesthetics in the Modern Social Order. Stanford University Press, pp. 184-197

11. Gottweis H (2003) Theoretical strategies of poststructuralist policy analysis: towards an analytics of government. In: Hajer M, Wagenaar H (Eds.) Deliberative Policy Analysis. Understanding Governance in the Network Society. Cambridge University Press, pp. 247-265

12. Gottweis H (2007) Rhetoric in Policy Analysis. In: Fischer F, Miller GJ, Sidney MS (eds) Handbook of Public Policy Analysis. Taylor \& Francis, London, pp 237-250

13. Hajer M, Wagenaar H (2003) Deliberative Policy Analysis. Understanding Governance in the Network Society. Cambridge University Press

14. Hajer M (2009) Authoritative Governance. Policy-making in the Age of Mediatization. Oxford University Press

15. Innes JE, Booher DE (2003) Collaborative policymaking: governance through dialogue. In: Hajer M, Wagenaar H (Eds.) Deliberative Policy Analysis. Understanding Governance in the Network Society. Cambridge University Press, pp. 33-59

16. Jasanoff S (2005) Designs on Nature. Science and Democracy in Europe and the United States. Princeton University Press

17. Kenneth D, Thompson PB (Eds.) (2008) What can Nanotechnology Learn From Biotechnology? Social and Ethical Lessons for Nanoscience from the Debate over Agrifood Biotechnology and GMOs. Elsevier

18. Krug, H. 7 Fragen zur Pressemitteilung des Umweltbundesamtes vom 21.10.2009. (Auszug aus der offenen Mail von Prof. H. Krug an das UBA). Published as press release by DECHEMA 22/10/2009. Retrieved from http://www. dechema.de/www.dechema.de/Stellungnahme_Harald_ Krug.html, last accessed Dec 2009

19. Lahl U (2006) Innovationsräume mit einem Risikoradar orten. Politische Ökologie, 24, p. 50-52. [Electronic version] Retrieved September 29, 2010, from http://www. dialog-nanopartikel.de/Lahl_Innovationsraeume.pdf

20. Luhmann N $\left(2000^{4}\right)$ Vertrauen. (Stuttgart: Lucius \& Lucius, UTB) (Original Luhmann 1968)

21. Macnaghten P, Kearnes M, Wynne B (2005) Nanotechnology, governance and public deliberation: what role for the social sciences? Sci Commun 27:268-291

22. Mehta M (2006) From Biotechnology to Nanotechnology: What Can We Learn from Earlier Technologies? In: Hunt 
G, Mehta M (Eds.) Nanotechnology: Risk, Ethics and Law. Earthscan, London/Sterling, pp. 121-129

23. Misztal B (1996) Trust in Modern Societies. Polity Press, Cambridge/Oxford/Malden

24. Mouffe C (2000) Deliberative Democracy or Agonistic Pluralism. Institut für Höhere Studien, Reihe Politikwissenschaft, Wien

25. Mouffe C (1993 (2005)) The Return of the Political. Verso, London/New York

26. NanoKommission der deutschen Bundesregierung (November 2008). Verantwortlicher Umgang mit Nanotechnologien. Bericht und Empfehlungen der NanoKommission der deutschen Bundesregierung 2008. Retrieved from http://www. bmu.de/files/pdfs/allgemein/application/pdf/nanokomm abschlussbericht 2008.pdf Last accessed Dec 9, 2010

27. Poortinga W, Pidgeon NF (2003) Exploring the dimensionality of trust in risk regulation. Risk Anal 23(5):961-972

28. Rogers-Hayden, T. \& Pidgeon, N. (2007). Moving Engagement 'Upstream'? Nanotechnologies \& the Royal Society and Royal Academy of Engineering's Inquiry. Special Issue, Public Understanding of Science, 16, p. 345-364.

29. Sørensen E, Torfing J (2005) The democratic anchorage of governance networks. Scand Polit Stud 28(3):195-218

30. Spiegel Online, 21. October 2009. Umweltbundesamt warnt vor Nanotechnologie. Retrieved from http://www. spiegel.de/wissenschaft/mensch/0,1518,656362,00.html, Last accessed December 3, 2010

31. Szerszynski B (1999) Risk and Trust: The Performative Dimension. Environ Values 8:239-252

32. Torfing J (2007) Introduction: Democratic Network Governance. In: Marcussen M, Torfing J (eds) Democratic Network Governance in Europe. Palgrave Macmillan, Basingstoke/ New York, pp 1-22

33. Torfing J (2007) Discursive Governance Networks in Danish Activation Policy. In: Marcussen M, Torfing J (eds) Democratic Network Governance in Europe. Palgrave Macmillan, Basingstoke/New York, pp 111-129

34. Federal Environment Agency/Umweltbundesamt (21.10.2009), Nanotechnik für Mensch und Umwelt - Chancen fördern und Risiken mindern, Presseinformation Nr. 75/2009

35. Wagenaar H, Cook N (2003) Understanding policy practices: action, dialectic and deliberation in policy analysis. In: Hajer M, Wagenaar H (Eds.) Deliberative Policy Analysis. Understanding Governance in the Network Society. Cambridge University Press, pp. 139-171

36. Weiss RS (1994) Learning from Strangers. The Art and Method of Qualitative Interview Studies. The Free Press, New York

37. Yanow D, Schwartz-Shea P (2006) Interpretation and Method. Empirical Research Methods and the Interpretive Turn. M.E. Sharpe, New York/London 